\title{
REVIEW OF HABITAT DISTRIBUTION, CONSERVATION STATUS AND HUMAN IMPACT: THE CASE OF ONE NATURA 2000 SITE IN THE EASTERN CARPATHIANS (ROMANIA)
}

\author{
Tudor Mihai URSU ${ }^{1}$, Sorina FARCAŞ ${ }^{1}$, Gheorghe COLDEA ${ }^{1}$, Ilie Adrian STOICA ${ }^{1}$, Marian PROOROCU \\ ${ }^{1}$ National Institute of Research and Development for Biological Sciences, Institute of Biological Research Cluj, \\ 48 Republicii str., RO-400015 Cluj-Napoca, Romania \\ ${ }^{2}$ University of Agricultural Sciences and Veterinary Medicine Cluj-Napoca, Faculty of Agriculture, \\ 3-5 Calea Mănăştur, RO-400372 Cluj-Napoca, Romania \\ e-mail: sorina.farcas@icbcluj.ro
}

\begin{abstract}
This paper focuses on the distribution of habitats in the Natura 2000 ROSCI0086 Găina-Lucina site, as well as on their conservation status and human impacts. The site analyzed is part of the Natura 2000 Network in Romania and is located in the region of Moldova. It has a total area of 848 ha. The habitat types for which the site has been declared are: 7110* - Active raised bogs, 91D0* - Bog woodland and 91E0* - Alluvial forests with Alnus glutinosa and Fraxinus excelsior (Alno-Padion, Alnion incanae, Salicion albae). Aside from the habitat types listed in the standard form, five additional ones of community interest have been identified: 6520 - Mountain hay meadows, 6510 - Lowland hay meadows (Alopecurus pratensis, Sanguisorba officinalis), 9410 - Acidophilous Picea forests of the montane to alpine levels (Vaccinio-Piceetea), 7140 - Transition mires and quaking bogs and 6430 Hydrophilous tall herb fringe communities of plains and of the montane to alpine levels. The data collected in the field has served to verify and correct the existing Standard Natura 2000 Form of the site. It represents the scientific foundation of the Management Plan, providing information on the distribution of the habitats, their conservation status, current and potential sources of human impact, and conservation measures needed to achieve and maintain a favourable conservation status for these habitats.
\end{abstract}

Keywords: Găina-Lucina SCI, habitat types, mapping, current pressures, future threats

\section{Introduction}

The protection and conservation of habitats, plants and wildlife in Romania is legislated by the Government Emergency Ordinance no. 57/2007 [28], approved by the Law 49/2011 [30]. This ordinance is the implementation in Romanian law of the concepts and instruments for action promoted in the Council Directive 92/43/EEC regarding the conservation of natural habitats, wild fauna and flora [23].

The Natura 2000 site Găina - Lucina (ROSCI0086) has been instituted for the conservation of several species and habitats of community interest mentioned in the $2 \mathrm{nd}$ and $3 \mathrm{rd}$ Annex of the Government Emergency Ordinance (GEO) no. 57/2007 [28], amended by the Order of the Minister for Environment and Forests no. 2387/2011 [31].

The site is located in Suceava county (coordinates of its centre: 47 $39^{\prime} 34^{\prime \prime} \mathrm{N}$ and $25^{\circ} 10^{\prime} 56^{\prime \prime} \mathrm{E}$ ), in the eastern part of the Romanian Carpathians. The altitude within the site varies between 1053 and 1387 m.s.m. The total area of the site is 848 ha. The limits for this site have been drawn in conformity with the Order of the Minister for Environment and Forests no. 2387/2011 [31] (Fig. 1). Within these limits, two nature reserves can be found. The first is the 
nature reserve "Tinovul Găina-Lucina", covering 1.1 ha, declared for the protection of flora and vegetation [24]. The second is the nature reserve "Cheile Lucavei", covering 34 ha, declared for the protection of geological, landscape and botanical elements [25]. Both reserves are included in the Law no. 5/2000 [29].

The habitats of community interest for which the site has been declared are, according to the standard data form: 7110* - Active raised bogs, 91D0* - Bog woodland, 91E0* - Alluvial forests with Alnus glutinosa and Fraxinus excelsior (Alno-Padion, Alnion incanae, Salicion albae). The general description and characterization of these habitat types can be found in the Natura 2000 interpretation manuals [27, 8, 9]. Additional information regarding the species and habitats for which the site has been declared was necessary. In order to have an effective management for biodiversity conservation, a detailed evaluation of existing biodiversity was needed, as well as an evaluation of human impact and of the degree of conservation for the habitats.

According to the data from the Natura 2000 Standard Data Form, the site Găina-Lucina has the following potential proportion of habitats, expressed as a percentage of the total 848 ha of the site: $7110 *$ - Active raised bogs $=50 \% ; 91 \mathrm{D} 0 *$ - Bog woodland $=50 \% ; 91 \mathrm{E} 0 *$ - Alluvial forests with Alnus glutinosa and Fraxinus excelsior $=1 \%$, the total being over $100 \%$. The field studies and habitat mapping have assisted in correcting these discrepant figures.

\section{Material and Methods}

In order to evaluate biodiversity, human impact and the conservation status of habitats, several field trips have been made on the site, between April and September 2012. The method used was that of the Central European Floristic School [2]. This methodology implies recording species data from the field in the form of phytocoenoses, used later to establish the natural habitat types. The technique used was that of "itinerary" investigations.

The succession of the research stages can be summarized as follows: a) the analytical stage, in which the members of the research team have identified in a correct and complete manner the qualitative, quantitative and spatial structure of phytocoenoses and natural habitats from the Council Directive 92/43/EEC [23]. In this stage, the distribution and spatial extent of these habitats was recorded, along with the intensity of anthropic and zoological pressure; b) the synthetic stage, taking part mostly in the laboratory, where the fragments of phytocoenoses analyzed have been merged in vegetation units (coenotaxonomic units/natural habitats). In addition, a succession scheme for plant communities has been drafted. The final result of this stage was the distribution map for the community habitats from the Natura 2000 site under investigation.

In the field, relevés have been recorded at the time of maximum affirmation of essential aspects for each phytocoenosis type (pre-vernal, vernal, aestival and autumnal). The site has been investigated in detail and relevés were collected from points considered to be representative, "key points", along pre-established transects. After each relevé has been recorded, observations and comparisons with the vegetation near the rélevés have been made, generalizing on the natural habitats from the investigated site.

Transects have focused on the 3 habitats of priority interest listed in the standard form: 7110* - Active raised bogs, 91D0* - Bog woodland and 91E0* - Alluvial forests with Alnus glutinosa and Fraxinus excelsior (Alno-Padion, Alnion incanae, Salicion albae). In order to 
select transects, several stages have been followed. The existing maps (topographical maps 1:50000 and 1:25000, aerial photography 1:5000), as well as polygons with the limits of the site and nature reserves (available by the Ministry of Environment and Forests) have been explored in the software ArcGIS 9.3.1, ESRI 2010 [26], while the site limits were also loaded in the Garmin CS60 GPS units. The correlation of topographical data and aerial photography with the information from the standard form has allowed drawing optimal transects for the study of community interest habitats from the site.

Transects have been represented in a graphic manner in ArcGIS 9.3.1. They have been updated later with information from the field, concerning the local particularities observed.

A qualitative and quantitative assessment of the habitats of priority interest has been performed, based on information regarding their floristic structure. Habitats different from those in the standard data form have also been recorded. The same activities have been implemented in the territory of the nature reserves Tinovul Găina - Lucina and Cheile Lucavei and have allowed us to identify and localize the types of habitats in the field. This information was later mapped in a GIS system, in the laboratory (Fig. 2). For each habitat type, the distribution was represented as polygon. The identification and mapping of habitats from the site was made at a scale of 1:10000. For the critical analysis of human impact, aerial photography was used, with $0.5 \mathrm{~m}$ pixel resolution, as well as topographical maps at different scales: 1:5000, 1:25000, 1:50000.

Using the existing information from these topographical supports, the major sources of potential human impact have been identified. These impact sources have been digitized, both from the area of the Natura 2000 site, as well as from neighboring areas, in a 5-km radius around the site (using a buffer function in the editing session of the ArcGIS software). Six different distances from the limits of the site have been taken into consideration, in order to reflect the gradual spatial distribution of the most important factors of human impact: $500 \mathrm{~m}, 1000 \mathrm{~m}, 2000$ $\mathrm{m}, 3000 \mathrm{~m}, 4000 \mathrm{~m}$ and $5000 \mathrm{~m}$.

In order to evaluate the real human impact on the protected area, detailed observations from the field were used. The human impacts have been identified; their location has been noted, as well as the intensity of manifestation and an estimation of how the surrounding habitats are affected. The identified impacts have been later ordered by intensity and by the severity of impacts on the studied habitats. After these data were collected from the field (from the nature reserves as well), they have been mapped in the laboratory. The resulting maps with information on the sources of human impact on the habitats of community interest were also used for the design of conservation measures needed to maintain the habitats and species of community interest within the site. Present-day impacts and potential threats have been analyzed for each habitat type or species of community interest.

\section{Results}

During our investigations in the field, we have collected information mainly on the three types of habitats listed in the standard data form of the site: 7110* - Active raised bogs; 91D0* Bog woodland; 91E0* - Alluvial forests with Alnus glutinosa and Fraxinus excelsior (AlnoPadion, Alnion incanae, Salicion albae). Aside from these habitats, five other habitats of community interest have been found and evaluated:

○ 6520 - Mountain hay meadows; 


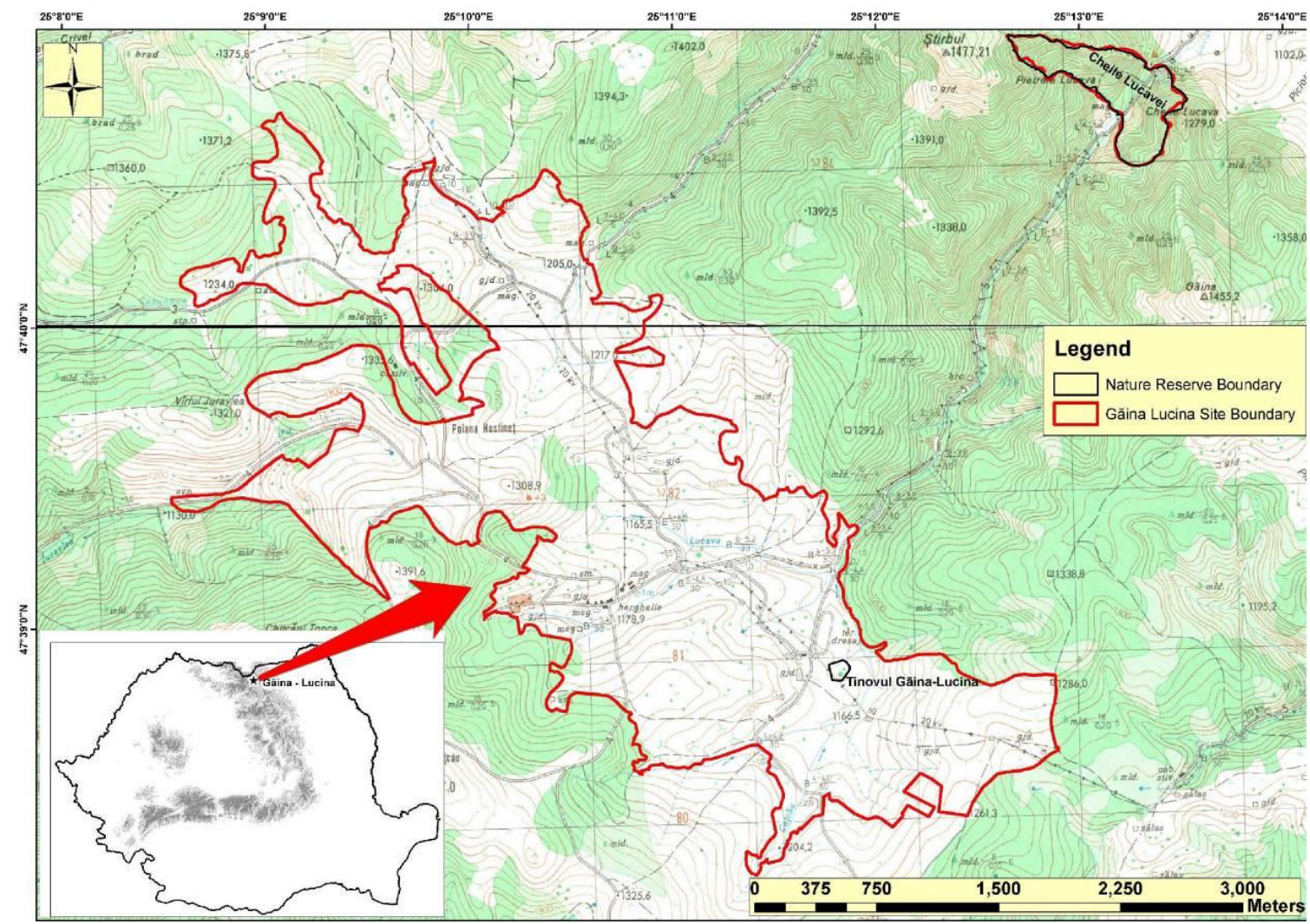

Fig. 1: Boundaries of the Natura 2000 site Găina - Lucina (ROSCI0086)

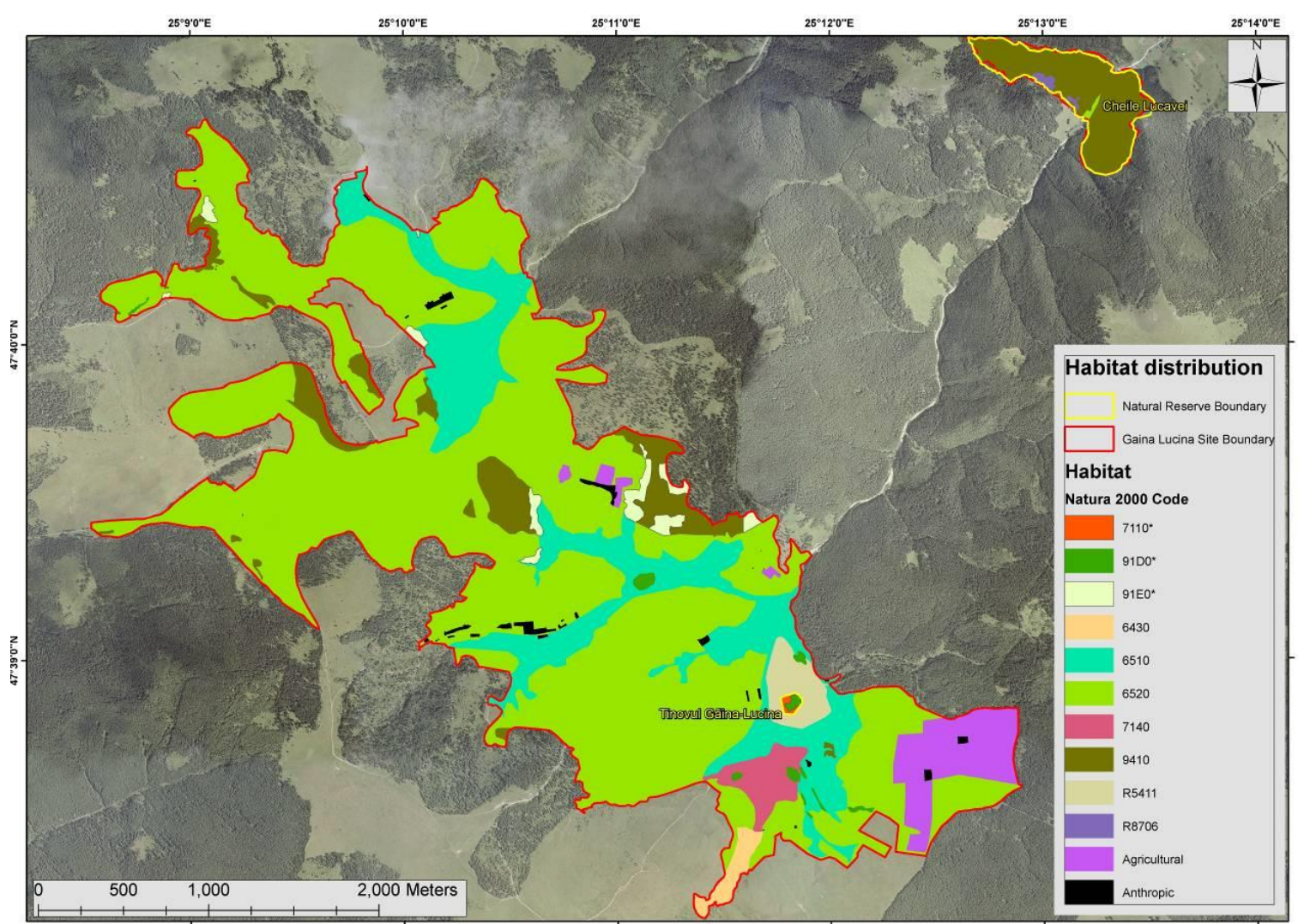

Fig. 2: Map of habitat distribution within the Natura 2000 site Găina - Lucina (ROSCI0086)

○ 6510 - Lowland hay meadows (Alopecurus pratensis, Sanguisorba officinalis); 
○ 9410 - Acidophilous Picea forests of the montane to alpine levels (Vaccinio-Piceetea);

- 7140 - Transition mires and quaking bogs;

○ 6430 - Hydrophilous tall herb fringe communities of plains and of the montane to alpine levels;

Other types of plant syntaxa have also been detected, corresponding to national habitat types R5411 ("South-East Carpathian marshes with Carex nigra ssp. nigra, Jungus glaucus and Juncus effuses") and R8707 ("South-East Carpathian communities with Calamagrostis arundinacea, Epilobium angustifolium and Atropa bella-donna").

The information from the field surveys has been used in the laboratory to create a map with the distribution of the three habitats of community interest listed in the standard form. This map was completed with the distribution of the other five types of habitats of community interest and with the distribution of the national habitat types (Fig. 2).

The habitats identified within the site have certain specific characteristics relating to the area occupied, their conservation status and composition in plant species and plant associations. Their distribution in the site is mainly determined by the environmental factors, but also by anthropogenic actions and will be detailed for each habitat.

The site comprises two areas: the main one, the Lucina depression, is dominated by grassland habitats while the second, the Cheile Lucavei reserve, is dominated by forest habitats. It is worth noting the human influence on the Lucina depression, which was originally covered by forests, but is now managed as pasture. Small patches from the former forests still exist in the Lucina depression, but their structure is strongly affected by human activity.

With regards to human impact, we have identified in the site and in the 5-km buffer zone the following sources of impact: 44 sheepfolds, 57 stables, 1 cottage, 7 forestry cottages, 2 farms, 4 localities and various roads. The activities with potential human impact have been structured in a list (Tab. 1). Using these categories of impacts, we mapped the distribution of current pressures (Fig. 3), as well as the distribution of future threats (Fig. 4).

\section{Discussions}

In Romania, Geographical Informatic Systems (GIS) and the resulting maps are a relatively recent approach in natural resource management. They have been used mostly in forest management [20, 13] and soil mapping [7, 22]. Only a few published articles make use of GIS maps and databases in planning the conservation measures for community interest species and habitats within the Natura 2000 Network [14, 12].

For each habitat, we have mapped the boundaries, threats and pressures and a short description of the situation recorded in the field was provided, focusing on their conservation status as well as on the human impacts that affect them.

\section{$7110^{*}$ - Active raised bogs}

This habitat has a natural origin at the site, its distribution being restricted to a small area in the Lucina depression. The bogs present here are included in the plant syntaxon Eriophoro vaginati - Sphagnetum recurvi Hueck 1925 [4, 6] and in the national habitat type R5101 - Mesooligotrophic peat bogs from the South Eastern Carpathians with Eriophorum vaginatum and Sphagnum recurvum. 
Table 1: List of current pressures and future threats with impact on the habitats

\begin{tabular}{|c|c|c|}
\hline Nr. & Parameter & Description \\
\hline 1 & \multirow{19}{*}{$\begin{array}{l}\text { Current } \\
\text { pressure }\end{array}$} & A03.02 Non-intensive mowing: practiced on delimited areas using fences. \\
\hline 2 & & A04.02.01 Non-intensive cattle grazing: practiced on delimited areas using fences. \\
\hline 3 & & $\begin{array}{l}\text { A04.02.02 Non-intensive sheep grazing: there is a sheepfold near the nature reserve } \\
\text { "Tinovul Lucina". }\end{array}$ \\
\hline 4 & & $\begin{array}{l}\text { A04.02.03 Non-intensive horse grazing: Lucina horse farm, in the grasslands from Lucina } \\
\text { depression }\end{array}$ \\
\hline 5 & & A05.01 Animal breeding: Lucina horse farm. \\
\hline 6 & & A05.02 Stock feeding: Lucina horse farm. \\
\hline 7 & & $\begin{array}{l}\text { A06.01.02 Non-intensive annual crops for food production: on small areas from the } \\
\text { southeastern part of the site; part of the fields from an experimental station for potato culture. }\end{array}$ \\
\hline 8 & & $\begin{array}{l}\text { B02.01.02 Forest replanting - non-native trees: Pinus sylvestris individuals planted a long } \\
\text { time ago. }\end{array}$ \\
\hline 9 & & $\begin{array}{l}\text { B07 Forestry activities not referred to above: cuts observed in the bog habitat with forest } \\
\text { vegetation. }\end{array}$ \\
\hline 10 & & D01.02 Roads, motorways: access road for the horse farm buildings. \\
\hline 11 & & $\begin{array}{l}\text { D02.01.01 Suspended electricity and phone lines: near the pension and near the } \\
\text { administrative buildings of the horse farm. }\end{array}$ \\
\hline 12 & & $\begin{array}{l}\text { E01.03 Dispersed habitation: administrative buildings of the horse farm, the pension offering } \\
\text { tourist accommodation. }\end{array}$ \\
\hline 13 & & $\begin{array}{l}\text { E04.01 Agricultural structures, buildings in the landscape: stables, administrative buildings } \\
\text { of the horse farm, buildings from the potato research station. }\end{array}$ \\
\hline 14 & & $\begin{array}{l}\text { H01.08 Diffuse pollution to surface waters due to household sewage and waste waters: sewer } \\
\text { waters from the pension and the administrative buildings of the horse farm. }\end{array}$ \\
\hline 15 & & $\begin{array}{l}\text { G01.02 Walking, horse-riding and non-motorized vehicles: walking, horse-riding (horse } \\
\text { farm tourists). }\end{array}$ \\
\hline 16 & & $\begin{array}{l}\text { G01.03.01 Regular motorized driving: auto access to the administrative buildings; access } \\
\text { with tractors. }\end{array}$ \\
\hline 17 & & $\begin{array}{l}\text { G05.09 Fences, fencing: The Lucina grassland is divided by fences. This management is } \\
\text { imposed by the horse farm administration. The Lucina bog and several parts of the bog } \\
\text { habitat are also fenced. }\end{array}$ \\
\hline 18 & & $\begin{array}{l}\text { H01.05 Diffuse pollution to surface waters due to agricultural and forestry activities: } \\
\text { pollution from the stables of the horse farms, originating mainly from manure deposits. }\end{array}$ \\
\hline 19 & & H05.01 Garbage and solid waste: garbage and residues from the stables \\
\hline 20 & \multirow{7}{*}{$\begin{array}{l}\text { Future } \\
\text { threats }\end{array}$} & $\begin{array}{l}\text { A04.01 Intensive grazing: if the number of horses in the farm would increase in a significant } \\
\text { manner; the same phenomenon would occur if the number of cattle or sheep would increase. }\end{array}$ \\
\hline 21 & & $\begin{array}{l}\text { A. } 04.02 \text {. Non-intensive grazing: access of domestic animals in the priority habitats not } \\
\text { protected by fences could affect their structure. }\end{array}$ \\
\hline 22 & & $\begin{array}{l}\text { B07 Forestry activities not referred to above: cutting trees in the site could have an impact on } \\
\text { all forest habitats: } 91 \mathrm{D} 0 * \text { - Bog woodland, 91E0* - Alluvial forests with Alnus glutinosa and } \\
\text { Fraxinus excelsior (Alno-Padion, Alnion incanae, Salicion albae), } 9410 \text { - Acidophilous } \\
\text { Picea forests of the montane to alpine levels (Vaccinio-Piceetea). }\end{array}$ \\
\hline 23 & & $\begin{array}{l}\text { C01.03.01 Hand-cutting of peat: has been practiced in the past and there is a risk it may } \\
\text { happen again. This would have a serious impact on all bog habitats. }\end{array}$ \\
\hline 24 & & $\begin{array}{l}\text { G01.04 Mountaineering \& rock climbing: if the tourism increases in the area, this may lead } \\
\text { to an increase in the impact caused by tourists in the site. }\end{array}$ \\
\hline 25 & & $\begin{array}{l}\text { H01.05 Diffuse pollution to surface waters due to agricultural and forestry activities: the } \\
\text { leaks from Lucina horse farm stables and from other places where manure is deposited could } \\
\text { lead to the enrichment in nutrients of certain habitats with low nutrient levels near these } \\
\text { locations. }\end{array}$ \\
\hline 26 & & $\begin{array}{l}\text { J02.01.02. Reclamation of land from sea, estuary or marsh drainage, used to recover land for } \\
\text { agriculture have been done in the past. There is a risk these activities could be revived, } \\
\text { having an impact on most of the habitats of concern in the site. }\end{array}$ \\
\hline
\end{tabular}

The restricted distribution of this habitat is caused by the strict environmental requirements (micro-relief, stagnant water) needed for its existence. However, these 
requirements are met on a larger surface in the site, so it is possible that this habitat had a larger distribution in the past. This hypothesis is even more likely given the fact that in the last decades, the drainage of bogs has been a common practice, driven by the need for larger areas for pastures [18]. Also, a warming trend in the last decades has been emphasized for the north-eastern part of Romania [15].

The habitat cover is currently under 1 ha and it was protected mainly because it provides conditions for the survival of an Arctic relict plant species, Betula nana [16]. The area of the habitat is now a nature reserve, named "Tinovul Găina-Lucina" [1]. The habitat also provides the conditions for survival of Ligularia sibirica, a plant species of community interest [21].

The bog is located in a small depression, on a gentle slope with an Eastern aspect, near one of the stables from the Lucina horse farm. In the best-conserved region, there is little shading from trees. The Sphagnum layer is well preserved and thick, with only a few vascular plant species, of which Eriophorum vaginatum has the most important cover. It is worth noting that Betula nana forms patches of compact shrubs in some locations, becoming the dominant species. According to palynological analysis data published by Pop [17], the bog had begun to form sometime in the Subboreal-Subatlantic interval, more than 3000 years ago.

Near the borders of the bogs, small pines have started to grow and may have an impact in the future composition of this habitat. Studies from the middle of the last century [19] note that peat has been extracted from this location before it was declared as a nature reserve. Later observations, from the 1970 s, note that granting the bog protection status helped, that it had regenerated and the population of Betula nana was expanding [18]. However, the same source also notes that the population of Pinus sylvestris had increased in cover compared to the period after 1950, and considers it as a potential threat to the bog.

Currently, there are several problems affecting this habitat. Traces of the drainage activities from the past still exist, as a ditch crosses the bog from the south-west to the north-east, which drains water from the bog and reduces humidity levels. These conditions probably existed also after 1960, when a "dry trend" was reported in the bog [19]. As the bog is located in a small depression, it receives water draining from the surrounding slopes and with it the mineral and organic nutrients from the area. As the ditch cuts straight through the bog, the role of natural buffer that intact peat would have had is diminished and these waters, which are rather rich in nutrients, flow through the meso-oligotrophic peat bog,

Another factor, which intensifies these processes, is the proximity of a stable, which is located above the bog. Given that this stable is actively used by the horse farm, it represents an important source of organic residue, which can be washed by the rain into the bog. This could change the specific of the bog from oligotrophic (poor in nutrients) to eutrophic (rich in nutrients). It is very likely that the expansion of pine and spruce in the bog is favoured by this phenomenon of nutrient enrichment and also by the decrease of the water level in the bog over the last decades. As regard to the species of community interest, Ligularia sibirica, it is not yet affected by these changes, being located near the edge of the bog, in an open area. This species also has wider ecological amplitude regarding the trophic levels [10, 11]. The populations of Betula nana may suffer in the future from shading from spruce and pine trees, as the species has high requirements for solar radiation.

It would be necessary to take measures against these tendencies, by reducing the nutrient levels in the vicinity of the bogs, and by reducing drainage of the peat bog habitats. These 
measures would neither significantly impede human activities in the area, nor influence the cover of pasture land within the site and would allow the habitat to be preserved in the future.

\section{D0* - Bog woodland}

This habitat is represented in the site by plant communities included in the national classification as habitat type R4412 - Open canopy forests in bogs from the South Eastern Carpathians with spruce - Picea abies and/or pine - Pinus sylvestris (plant syntaxon Sphagno Piceetum Hartm. 1942)[4]. This habitat has a larger cover compared to that of active bogs, but it is still a relatively scarce habitat, with 4 ha of island-like distribution, mostly in the south-eastern part of the site, in the valley of the Lucava River.

The habitat has similar requirements for environmental factors to the previous habitat (active bogs), as it develops on flat areas or in small depressions, where water stagnates and there are few nutrients available (oligotrophy). It is possible for this habitat to expand in the future and colonize former bogs degraded by human intervention (mostly by nutrient enrichment). In such cases, these tree communities have a lower priority for conservation compared to the possible restoration of the original bog habitats. Depending on the level of nutrients in the substrate, we found typical areas for the habitat, dominated by Pinus sylvestris and occasionally by Picea abies. We also found it in areas richer in nutrients, with Salix and Alnus incana in their structure, marking a transition to the habitat type 91E0* - Alluvial forests with Alnus glutinosa and Fraxinus excelsior (Alno-Padion, Alnion incanae, Salicion albae). In the areas with low nutrients, typical species appear, such as Eriophorum vaginatum and Oxycoccus microcarpus, which are proof for the conservation of the specific of the habitats.

As these are forest habitats, there is a risk that they will be targeted for exploitation. Activities of tree cutting have been noticed only in one location and this may be caused in part by the difficult access due to the peat layer and increased humidity. The greater risk for these habitats is also a change in nutrient levels and the transition towards alluvial forests, with soils rich in nutrients. Another risk for these forests would be their drainage.

91E0* - Alluvial forests with Alnus glutinosa and Fraxinus excelsior (Alno-Padion,

Alnion incanae, Salicion albae)

The habitat is represented in the site by Alnus incana forests, included in the national classification as habitat type R4401 - South East Carpathian forests with grey alder - Alnus incana and Telekia speciosa, belonging to plant community Telekio speciosae-Alnetum incanae Coldea (1986) 1991 [4].

It has a patchy distribution in the site, on the banks of creeks, especially where the water flow is reduced and the soils are excessively humid. Such conditions occur mostly in the basin of the Lucina River. This habitat has a total cover of 10 ha, making it the largest of the three habitats of community interest in the site. The more extended cover is likely a consequence of a wider niche, as this habitat is less affected by nutrient enrichment.

Previous studies in the Lucina depression mention several peat bogs in the Lucina river basin, in locations where we found this habitat. It is very likely that these bogs have been drained and their nutrient levels have increased and as a result, alluvial forest communities have eventually colonized them.

It is important to notice that these habitats also provide conditions for the survival of Ligularia sibirica, an endangered species of community interest. The site comprises both mature alder forests with trees more than $10 \mathrm{~m}$ high and a closed canopy, and young alder forests with 
small trees and an open canopy.

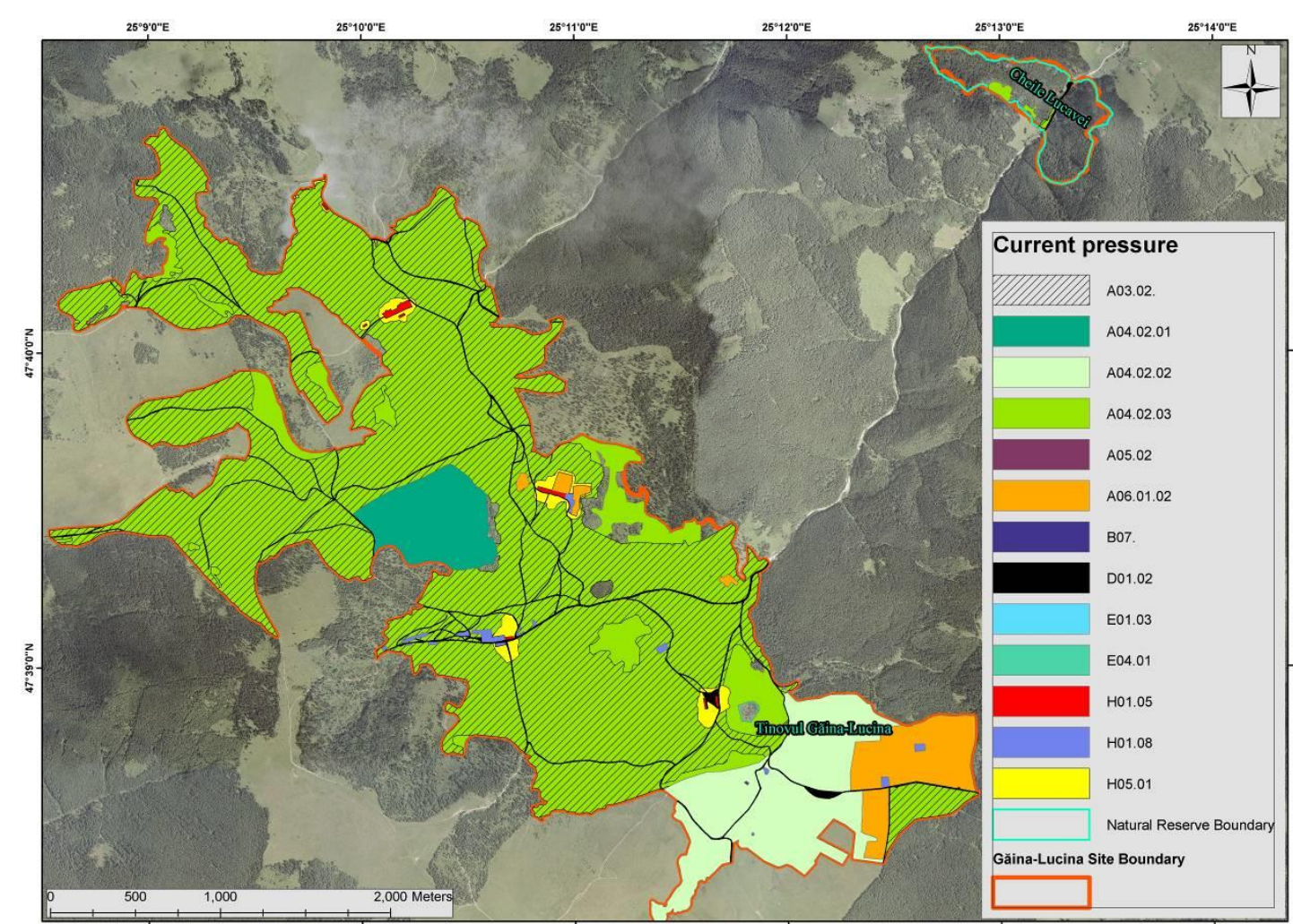

Fig. 3: Distribution of current pressures on the habitats within ROSCI0086 Găina-Lucina

Patches of alluvial forest and some Ligularia sibirica populations extend beyond the site boundaries, in the near vicinity. Extending the site boundaries to include them would be desirable, as these areas may prove important for the conservation of the habitat and of Ligularia sibirica in the future, particularly since the populations of this species are not considered to be well protected within the Romanian Natura 2000 Network [12].

While fences protect the bog habitats from the valley of the Lucava River at least partially, the alder forests are in general accessible for animals and this may be a factor of risk for the species composition. Alder forests are also exposed to a certain degree to the risk of exploitation (tree cutting), but alder wood is not much valued. Another possible risk would be water drainage, which needs to be avoided.

\section{0 - Mountain meadows}

This type of grassland is included in the national classification as habitat type R3803 South Eastern Carpathian pastures with Agrostis capillaris and Festuca rubra, syntaxon Festuco rubrae - Agrostetum capillaris Horvat 1951 [5]. These occupy most of the site (more than 500 ha). They are widely distributed in the site, both on the hill tops and on the slopes. These habitats are secondary communities, installed after the clearing of spruce forests in the area. As slopes are generally moderate in the site, the aspect of the slopes has almost no influence on the habitat type, as would be expected. Aspect does influence the abundance of certain accompanying species, but it does not change the community type. 


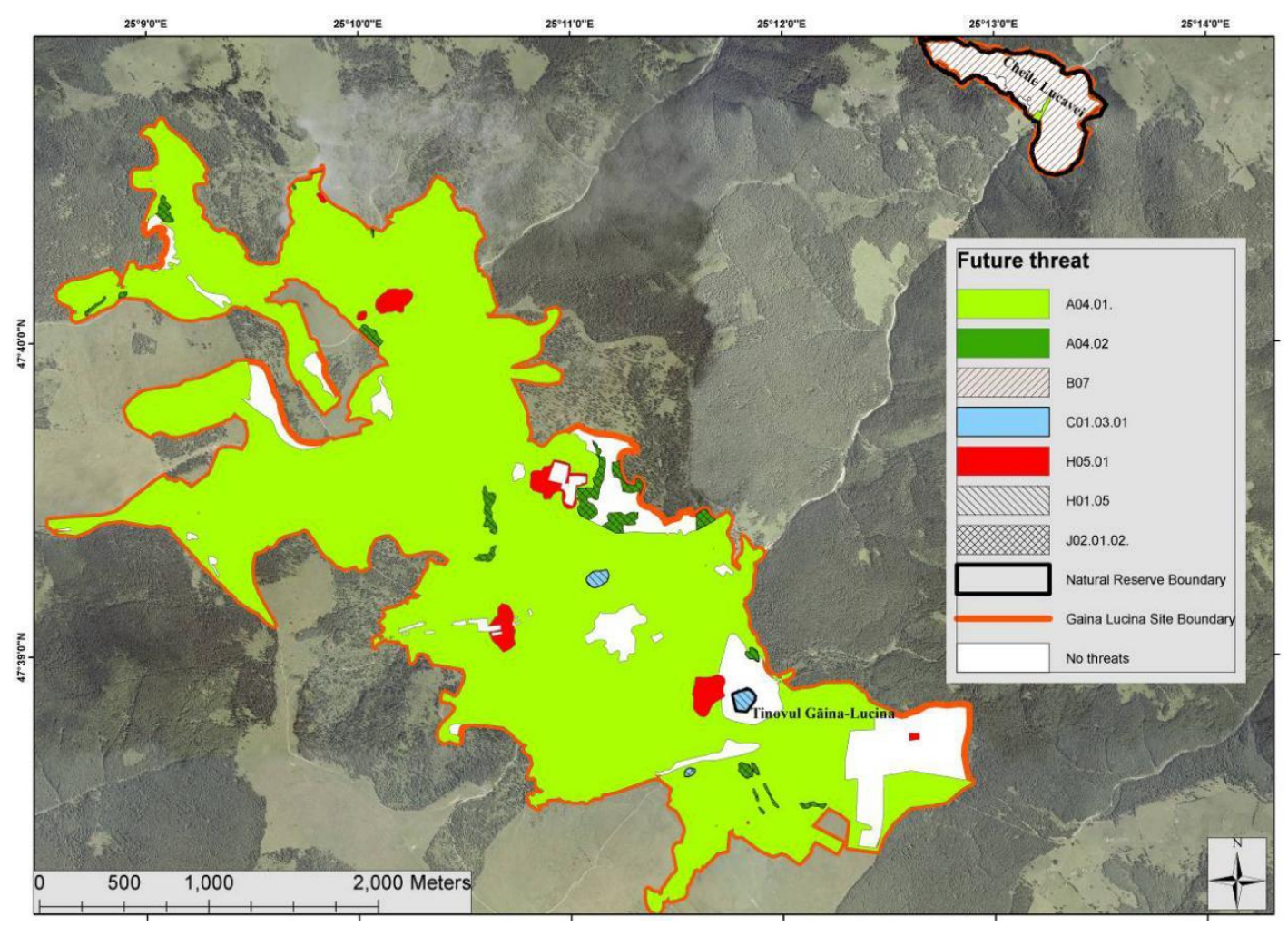

Fig. 4: Distribution of future threats on the habitats within ROSCI0086 Găina-Lucina

These grasslands are used in general as pastures and some as hay-meadows. Land use is in some cases changed from one year to the other. This change is facilitated by the fact that many grasslands are enclosed by fences and the access of large animals (mostly horses) is under control. In some small areas, the grassland structure is degraded by overgrazing - in locations where animals are kept for longer periods. In these cases, the grasslands begin to change towards Nardus-dominated grasslands. A stronger impact on the grassland structure is the change in nutrient levels, near stables and in areas where organic residue is deposited. In such locations, nitrophilous plant species appear, such as Rumex alpinus and Urtica dioica.

In general, the management of the grassland is balanced, which is reflected in the natural composition of the habitats in most areas from the site. Maintaining this management is a requirement for the conservation of the habitat.

\section{0 - Lowland hay meadows (Alopecurus pratensis, Sanguisorba officinalis)}

These grasslands are part of the national habitat type R3802 - Dacic-Getic grasslands with Arrhenatherum elatius, plant syntaxon Arrhenathetum elatioris Br.-Bl. ex Scherrer 1925 [5]. They occupy a significant part of the site - more than 100 ha. They develop in the lower half of slopes and in meadows, where the soil is moist and fertile. These conditions are met in the basins of the Lucina and Lucava rivers.

The grasslands of this type have high value as fodder and are characterized by many vigorous grasses, such as Festuca pratensis, Dactylis glomerata, Alopecurus pratensis, Phleum pratense, Poa pratense, Lolium perenne and by several Fabaceae species such as Vicia sepium, $V$. striata, Trifolium pratense, T. repens and T. hybridum. In these grasslands we noticed the species Trollius europaeus in several locations, a species declared a "monument of nature" in Romania. These grasslands are also under a balanced management, which is required to ensure 
the survival of the habitat in good condition.

\section{0 - Acidophilous Picea forests of the montane to alpine levels (Vaccinio-Piceetea)}

Spruce forests from the site are included in the national habitat type R4205 - South East Carpathian spruce forests with Oxalis acetosella, plant syntaxon Hieracio rotundati - Piceetum Pawl et Br. Bl. 1939 [4]. They are located mostly in the perimeter of the nature reserve "Cheile Lucavei". Small patches, with open canopy and perturbed structure, can also be found in the Lucina depression. The total area occupied by the spruce forests in the site is about 50 ha.

In the nature reserve, spruce covers both slopes of the Lucava valley. These slopes are rather steep - 30-40 - and have limestone as their geological substrate while the dominant soils are of rendzina type. The forests on the right side of the valley, with north-western aspect, have more mesophilic plant species in the herbaceous layer, but with a reduced abundance. The forests on the left side of the valley receive more solar insolation, which favours herbaceous species, especially meso-xerophilic plants. The forests found on this slope offer conditions for several basiphilous plant species, such as Astrantia major, Cirsium erisithales, Laserpitium latifolium or Carduus glaucus, while the rocks on both sides of the valley harbour calcicolous species such as Campanula carpatica, Leontopodium alpinum and Saussurea discolor. However, habitats specific to open rocks were not recorded, as the open rocks are isolated and rather small in size and the specific plants are represented only by isolated individuals.

With regard to the management of this forest type, the forests from "Cheile Lucavei" have kept their natural structure, probably helped by the status of nature reserve, but also by the steep slopes, which make access difficult, even if they are in the vicinity of a settlement and an access road.

\section{0 - Transition mires and quaking bogs}

These bogs are included in the national habitat type R5403 - South - Eastern Carpathian meso-oligotrophic bogs with Carex rostrata and Sphagnum recurvum, plant syntaxon SphagnoCaricetum rostratae Steffen 1931 [3]. The total cover of this habitat in the site is $\sim 10$ ha. The habitat is mostly located in the Lucava river valley, on flat substrates with excessive humidity, but with more nutrients compared to the active bogs. These plant communities encircle the bog islands with forest vegetation found in the Lucava valley.

These habitats have a series of species in common with the other two bog habitats on the site, such as Sphagnum recurvum, Eriophorum vaginatum, Carex rostrata, Carex pauciflora and Galium uliginosum, but they also have species which occur usually in oligo-mesotrophic and mesotrophic moist areas, such as Carex canescens, Carex nigra, Ranunculus acer, Geum rivale and Comarum palustre. Management measures needed for the preservation of this habitat are similar to those presented above for active bogs. It is worth mentioning that this habitat is somewhat less sensitive to nutrient enrichment compared to active bogs.

6430 - Hydrophilous tall herb fringe communities of plains and of the montane to alpine levels

This habitat can be found on the site in small areas. They are included in the national habitat type R3708, Dacic-Getic communities with Angelica sylvestris, Crepis paludosa and Scirpus sylvaticus, plant syntaxon Scirpetum sylvatici Ralski 1931 emend. Schwich 1944 [5]. 
The habitat is present only in the southern part of the site, near a stream. It has an atypical structure and only the abundance of the species Scirpus sylvaticus suggests that the community is a part of this habitat.

\section{R8706 - South Eastern Carpathian communities with Calamagrostis arundinacea,} Epilobium angustifolium and Atropa bella-donna

The plant communities present in the site, belonging to Epilobietum angustifolii Rübel 1930 emend. Oberd. 1973 [5], are characteristic to areas where vegetation succession occurs and they can be found in the site in forest clearings from the nature reserve "Cheile Lucavei". These communities are temporary as Picea abies saplings are already present in them, in a few years these herbaceous communities turning into young spruce forests.

R5411 - Eu-mesotrophic bogs from the Southeastern Carpathians, with Carex nigra ssp. nigra, Juncus glaucus and J. effusus

These communities, belonging to Junco-Caricetum fuscae Tx. (1937) 1952 [4], appear in moist places with limited nutrients, where the soil reaction is less acidic and the trophic input is higher, compared to the bogs listed above. These conditions make it impossible for Sphagnum species to develop. They can be found in the site on about 10 ha, mostly in the Lucava valley, encircling the active bogs from the nature reserve "Tinovul Găina". They have several species characteristic of mesotrophic bogs, such as Agrostis canina, Ranunculus acris, Cirsium palustre, Carex echinata, Filipendula ulmaria and Juncus effusus, which serve to indicate the increased nutrient levels. These communities are more resilient to drainage activities and are less affected by nutrient enrichment.

\section{Conclusions}

The research from Natura 2000 site Găina - Lucina (ROSCI0086) brings new and important information regarding the structure and distribution of the community interest habitats. This research has served to clarify the conservation status of the habitats and the human impact from the site. Eight types of habitats of community interest have been mapped, as well as two national habitats. The conservation levels of these habitats have been recorded, and 26 human activities have been identified, representing current pressures and future threats with potential impact on the site. The information collected, together with the resulting GIS maps and database, contributed to the elaboration of the Management Plan for the site and was used to update the Standard Form of the site, and to offer a scientific argument for the management measures that are to be enforced for the sustainable development of the site. This information can also serve to raise awareness among the local population and administrative institutions.

Acknowledgements: This research was supported by Sectoral Operational Programme, Environment Axis 4, under the Ministry of the Environment and Climate Change coordination, within the framework of the SINCRON Project, managed by the National Agency for Environmental Protection.

\section{REFERENCES}

1. Brega, P., Filipaşcu, A., Seghedin, T.G., Boşcaiu, N., 1973, Semnificaţia ecologică a rezervaţiilor naturale 
din jud. Suceava, Studii şi Comunicări de Ocrotirea Naturii Suceava, 3: 5-10.

2. Braun-Blanquet, J., 1964, Pflanzensoziologie. Grundzüge der Vegetationskunde, Springer Verlag, Wien.

3. Coldea, G., 1973, Contribuţii la studiul clasei Scheuchzerio-Caricetea fuscae Nordth. 36 din România (II), Hidrobiologia, 14: 161-175.

4. Coldea, G., 1991, Prodrome des associations végétales des Carpates du sud-est - Carpates Roumaines. Documents Phytosociologiques, Nouvelle Série, Camerino, 13: 317-539.

5. Coldea, G., Oprea, A., Sârbu, I., Sîrbu, C., Ştefan, N., 2012, Les associations végétales de Roumanie (Tome 2. Les associations anthropogènes), Presa Universitară Clujeană, Cluj-Napoca.

6. Coldea, G., Sanda, V., Popescu, A., Ştefan, N., 1997, Les associations végétales de Roumanie (Tome 1. Les associations herbacées naturelles), Presa Universitară Clujeană, Cluj-Napoca.

7. Dincă, L., Spârchez, G., Dincă, M., 2014, Romanian's Forest Soils Gis Map And Database And Their Ecological Implications, Carpathian Journal of Earth and Environmental Sciences, 9 (2): 133-142.

8. Doniță, N., Popescu, A., Biriş, I.A., Paucă-Comănescu, M., Mihăilescu, S., 2005, Habitatele din România, Editura Tehnică şi Silvică, Bucureşti.

9. Gafta, D., Mountford, J.M., 2008, Manual de interpretare a habitatelor Natura 2000 din România, Editura Risoprint, Cluj-Napoca.

10. Heinken-Šmídová, A., Münzbergová, Z., 2012, Population dynamics of the endangered, long-lived perennial species, Ligularia sibirica, Folia Geobotanica, 1-22.

11. Kukk, Ü., 2003, The distribution of Ligularia sibirica (L.) Cass. in Estonia and changes in its population, Biuletyn Ogrodów Botanicznych, 12: 11-22.

12. Mânzu, C., Gherghel, I., Zamfirescu, Ş., Zamfirescu, O., Roşca, I., Strugariu, A., 2013, Current and future potential distribution of glacial relict Ligularia sibirica (Asteraceae) in Romania and temporal contribution of Natura 2000 to protect the species in light of global change, Carpathian Journal of Earth and Environmental Sciences, 8 (2): 77-87.

13. Osaci-Costache, G., Ene, M., 2010, The analysis of forest dynamics within the Carpathians - the Subcarpathians contact area by using the historical cartography approach and open source Gis software. Case study: the Limpedea catchment (Romania), Forum Geografic, Studii şi cercetări de geografie şi protecţia mediului, 9: 115-124.

14. Petrişor, A.-I., 2010, GIS analysis of wetland cover by NATURA 2000 sites, Environmental Engineering and Management Journal, 9 (2): 269-273.

15. Piticar, A., Ristoiu, D., 2012, Analysis of air temperature evolution in Northeastern Romania and evidence of warming trend, Carpathian Journal of Earth and Environmental Sciences, 7 (4): 97-106.

16. Pop, E., 1928, Betula nana L. şi Betula humilis Schrk. în România, Buletinul Grădinii Botanice şi Muzeului Botanic Universitatea Cluj, 8 (1): 1-9.

17. Pop, E., 1929, Analize de polen în turba Carpaţilor Orientali (Dorna-Lucina), Buletinul Grădinii Botanice şi Muzeului Botanic Universitatea Cluj, 9: 81-210.

18. Pop, E., Boşcaiu, N., Rădulescu, D., 1973, Eficienţa ecologică a măsurilor pentru protecţia tinovului de la Lucina - Jud. Suceava, Studii şi Comunicări de Ocrotirea Naturii Suceava, 21-28.

19. Raclaru, P., Barbu, N., 1959, Studiu floristic şi geobotanic asupra cuvetei Lucina - Bucovina, Iaşi, Analele Ştiinţifice ale Universităţii „,Al. I. Cuza” secţiunea II - Ştiinţe Naturale, 1: 81-109.

20. Săvulescu, I., Bogdan, M., 2012, Geographic information system (GIS) application for windthrow mapping and management in Iezer Mountains, Southern Carpathians, Journal of Forestry Research, 23 (2): 175-184.

21. Stoicovici, L., 1982, Răspândirea populaţiilor relictare de Ligularia sibirica (L.) Cass. în R.S.R, Studii şi Cercetări de Biologie seria Biologie Vegetală, 34 (1) : 14-19.

22. Vintilă, R., Munteanu, I., Cojocaru, G., Radnea, C., Turnea, D., Curelariu, G., Nilca, I., Jalbă, M., Piciu, I., Râşnoveanu, I., Şileţchi, C., Trandafir, M., Untaru, G., Vespremeanu, R., 2004, The Geographic Information System of Soil resources of Romania,,SIGSTAR-200": Development and main types of applications, Lucrările celei de a XVII-a Conferinţe Naţionale pentru Ştiinţa Solului, 34A: 439-449.

23. $* * *$ Council Directive $92 / 43 / \mathrm{EEC}$ regarding the conservation of natural habitats, wild fauna and flora, JO L 206, 22.7.1992, with modifications.

24. ***Decision $433 / 1971$ of the Suceava County Council.

25. *** Decision 492/1973 of the Suceava County Council.

26. ***ESRI ArcGIS Desktop: Release 9.3.1., 2010, Redlands, CA, Environmental Systems Research Institute. 
27. ***EUR 27/2007, Interpretation Manual of European Union Habitats, European Commission Dg. Environment, Nature and biodiversity, 142 pages.

28. ***GEO 57/2007, regarding the regime of natural protected areas, natural habitats conservation, wild flora and fauna, published in the Official Gazette, 442/2007.

29. ***Law no. 5/2000 regarding the approval of the National Spatial Plan - Section III- protected areas, published in the Official Gazette, 152/2000.

30. ***Law no. 49/2011 regarding the approval of GEO 57/2007, published in the Official Gazette, 262/2011.

31. ***OMEF $2387 / 2011$ for the modification of OMMDD 1964/2007 (O.G. 98/2008) regarding the institution of the protected area regime for Sites of Community Importance, as integral part of the European Natura 2000 ecological Network in Romania, published in the Official Gazette, 846/2011.

\section{EVALUAREA DISTRIBUŢIEI HABITATELOR, STĂRII DE CONSERVARE ŞI IMPACTULUI ANTROPIC: CAZUL UNUI SIT NATURA 2000 DIN CARPAȚII ESTICI (ROMANIA)}

\section{(Rezumat)}

Lucrarea prezintă distribuţia habitatelor în situl Natura 2000 ROSCI0086 Găina-Lucina, starea de conservare a acestora, presiunile şi ameninţările antropice precum şi măsurile de conservare necesare. Habitatele pentru care situl a fost declarat sunt 7110* - Turbării active, 91D0* - Turbării cu vegetaţie forestieră şi 91E0* Păduri aluviale cu Alnus glutinosa şi Fraxinus excelsior. În sit au mai fost identificate 5 alte habitate de interes comunitar: 6520 - Fâneţe montane, 6510 - Pajişti de altitudine joasă, 9410 - Păduri acidofile de Picea abies din regiunea montană, 7140 - Mlaştini turboase de tranziţie şi turbării oscilante şi 6430 - Comunităţi de lizieră cu ierburi înalte higrofile. 